\title{
ON CURRENT PROPOSALS TO LEGALIZE WIRE TAPPING *
}

\author{
Louis B. Schwartz $\dagger$
}

On wire tapping, as on most problems of the penal law, where one comes out depends largely on the attitudes and assumptions which one brings to the controversy. At one extreme, one may believe that social order depends almost entirely on punishment by law, and requires capture, conviction and severe treatment of as many culprits as possible. At the other extreme is the view that all criminal law is simply crudely disguised vengeance, that jail and capital punishment are pointless cruelties deterring no one, embittering more criminals than they reform, and inflicting less pain on the guilty than on their innocent dependents. Between these two extremes is a third position that may commend itself to moderates. This position accepts the hypothesis of deterrence by example, but not the proposition that the best penal system is the one that produces convictions and sentences in $100 \%$ of the cases of crime. The paradoxical fact is that arrest, conviction, and punishment of every criminal would be a catastrophe. Hardly one of us would escape, for we have all at one time or another committed acts that the law regards as serious offenses. Kinsey has tabulated our extensive sexual misdeeds. The Bureau of Internal Revenue is the great archive of our false swearing and cheating. The highway death statistics inadequately record our predilection for manslaughter. $100 \%$ law enforcement would not leave enough people at large to build and man the prisons in which the rest of us would reside. Somehow

* This article is based on an address delivered at the Seventeenth Annual Judicial Conference, Third Judicial Circuit of the United States, September 9, 1954. Footnotes have been supplied by the editors.

As introduced, the bill receiving Administration support, H.R. 8649, 83d Cong., $2 \mathrm{~d}$ Sess. (1954), proposed by Rep. Kenneth Keating, authorized the admission of wire tap evidence procured before or after the effective date of the Act with the Attorney General's approval in criminal cases involving the national security or defense of the United States. Divulgence or publication of this information for other purposes is punishable by fine or imprisonment. When approved by the House of Representatives, the bill was amended to require that an authorization for a wire tap be secured from a federal judge if the evidence thus obtained is to be admissible.

The bill proposed by the late Senator Pat McCarran, S. 3229, 83d Cong., 2d Sess. (1954), prohibited unauthorized wire tapping but permitted interceptions in security cases which are made with the approval of the Attorney General and pursuant to a court order 'This order would be effective for six months with possibility of renewal. Information so obtained would be admissible in evidence.

$\dagger$ Professor of Law, University of Pennsylvania Law School. 
we manage to conduct a fairly orderly, stable society although arrests are made in a small percentage of the offenses committed, and convictions lag very far behind arrests.

A penal system gives us about all we can get out of it if apprehension and punishment are pursued and inflicted with sufficient determination that a would-be law violator must count them as substantial risks. The escape of an occasional or even many guilty individuals, because of the procedural safeguards that we accord to the accused, is therefore a tolerable price to pay for the preservation of an atmosphere of freedom and respect for individuality. Anglo-American societies have willingly paid this price for many centuries. Consider the number and variety of escape hatches for criminals built into our traditional and constitutional structure: the rule against searching a suspect or his house or his papers except on reasonable grounds previously exhibited to a judge; the requirement that prosecution witnesses tell their story in court, in the presence of the accused; the necessity that accomplice testimony be corroborated; the privilege against self-incrimination; the right to prevent one's spouse or lawyer from testifying to the crimes one has admitted in confidence; the constitutional necessity to produce two witnesses to an overt act of treason; the requirement of proof beyond a reasonable doubt; the right of trial by jury with the concomitant opportunity of the defendant to avoid punishment if a single juror, however obtuse, remains unpersuaded.

One stands amazed at these products of 1000 years of AngloAmerican experience in restraining law enforcement. Make no mistake about it. These are not rules for the protection of the innocent alone. They are rules which operate and were intended to operate before anyone could decide whether the suspect was innocent or guilty. They are rules which are availed of in the vast majority of cases by persons more likely guilty than not. Their peculiar usefulness to the "guilty" is no accident, for many of these rules were written into the Constitution by real "criminals," fresh from experience as smugglers, tax evaders, seditionists and traitors to the regime of George III. Theirs was no mawkish sentimentality for miscreants. They understood, as we must understand, that the law enforcement net cannot be tightened for the guilty without enmeshing the innocent; that decent law enforcement is possible without impairing the bulwarks against injustice and tyranny; and that the worth of a society will eventually be reckoned not in proportion to the number of criminals it crucifies, burns, hangs or imprisons, but rather by the degree of liberty experienced by the great body of its citizenry. There have never been more determined law enforcers than Nazi Germany or the Soviet. 
Accordingly, moderates in law enforcement, while ready to give the Government the powers it needs to investigate and punish treason or espionage, will not be stampeded into legislation subversive of the great right to be let alone merely because an occasional conviction may be lost. Moreover, in conceding the Government such powers as the privilege to eavesdrop on telephone conversations, if specific need for that can be shown, moderates will demand a careful definition of the power and the maximum practicable safeguards.

\section{The Need for New Wire Tapping Legislation Has Not BeEN Shown}

Any consideration of wire tapping proposals must begin with the question whether and why we need it. Even ardent proponents of wire tapping do not regard it as an unmixed blessing. They recognize that costs and dangers are involved, and see themselves therefore as taking a calculated risk to meet the necessities of national defense or of a broader war against crime. What then do we know of this so-called necessity? The congressional hearings ${ }^{1}$ offer little but reiterated expressions of opinion by representatives of the Defense and Justice Departments. Were it not for the high position of the authors of these opinions, the wire tapping case would fail at this point for want of prosecution. The people can hardly be expected to submit themselves to a more intrusive police surveillance merely because some officials express the view that it will be a good thing. Nevertheless, when the official views are sponsored by Presidents as far apart as Franklin Roosevelt and Dwight Eisenhower, and by Attorneys General as diverse as Jackson, Clark, Biddle and Brownell, it becomes our duty at least to endeavor to imagine the factual basis for the requested power. If, after this exercise, we remain unconvinced, we shall be in such distinguished company as the Bar Associations of Chicago and New York City. These organizations opposed the wire tapping bills before the Senate Judiciary Committee. Chicago declared that Congress should not act until proponents had carried the burden of proof that the threat to national security is "great enough to justify departure from the normally sound policy of prohibiting wire tapping altogether." ${ }^{2}$ New York said: "Unfortunately, no Attorney General has cited data or instances where wire tapping was the only feasible way of acquiring information of

1. Hearings before Subcommittee No. 3 of the House Committee on the Judiciary on H.R. 408, H.R. 477, H.R. 3552 and H.R. 5149, 83d Cong., 1st Sess. (1953). Hearings before a Subcommittee of the Senate Conmittee on the Judiciary on S. 832, S. 2753, S. 3229 and H.R. 8649, 83d Cong., 2d Sess. (1954).

2. Senate Hearings, supra note 1 , at 236. 
crimes affecting the national security, or where, without the use of wire taps, the course of an investigation would have been seriously impeded." 3

During my own four years in the Criminal Division of the Department of Justice I must have reviewed thousands of FBI reports. I helped write Supreme Court briefs in the second Nardone case, ${ }^{4}$ which forbade indirect use of wire taps, the $W$ eiss case, ${ }^{5}$ excluding from evidence intrastate communications obtained by wire tapping, and the Goldman case ${ }^{b}$ approving the use of the detectaphone, a device placed on the exterior wall of an apartment for the purpose of amplifying sound waves coming through the wall. I argued as effectively as I could for the necessity of the surveillance devices. But, looking back, it is clear that there never was a showing or even a serious attempt to show that we would catch fewer criminals or that criminal activity would increase in case of the unavailability of the surveillance devices involved. All we could prove, and I think all that the current talk of necessity means is that the prosecution will lose a particular conviction, as in the Coplon case, ${ }^{7}$ when it becomes known that an illegitimate detection device has been employed. This does not prove that future Coplon cases cannot be found and successfully prosecuted by more orthodox procedures. Nor is it reasonable to suppose that the failure of the Coplon prosecution has encouraged or increased espionage activity. A traitor who risks death if apprehended is certainly not going to be deterred by the knowledge that his telephone may be tapped; at most, he will avoid use of the telephone. Our national survival through four terrible decades of world war and revolution is almost alone sufficient to raise doubt regarding the present necessity of resort to wire tapping for self-preservation.

The core of the argument of necessity is no more than this: in some cases wire tapping may be the easiest way to secure evidence. Or, putting it another way, alternative methods of investigation would be more expensive. For example, if wire tapping be forbidden, an extra agent may have to be assigned to shadow the suspect, or a little more time or care taken to assure that the arrest will be made after the suspect has passed the incriminating documents to his fellow-spy. It is not even certain that these alternatives would in the long run prove

3. $I d$. at $118-19$.

4. Nardone v. United States, 308 U.S. 338 (1939).

5. Weiss v. United States, 308 U.S. 321 (1939).

6. Goldman v. United States, 316 U.S. 129 (1942).

7. United States v. Coplon, 185 F.2d 629 (2d Cir. 1950), cert. denied, 342 U.S. 920 (1952); 191 F.2d 749 (D.C. 1951), cert. denied, 342 U.S. 926 (1952). The retroactive provisions of the Keating bill would probably permit the admission of wire tap evidence in another Coplon trial. See star note at p. 157 supra. 
more expensive or less efficient than wire tapping, which makes protracted demands on skilled men and equipment, and must in many cases be completely unrewarding. It is conceivable that enforcement people are fascinated by wire tapping somewhat in disregard of rational considerations of cost. There is a certain satisfaction in being the unseen viewer, the unknown overhearer of the private exchanges of others. Besides, the police of all ages have known that damaging evidence obtained from the lips or precincts of the accused himself commands an almost overwhelming credit. The temptation to seek this kind of evidence has therefore been well nigh irresistible. One era approves of torture to secure such self-incrimination. Another will give its lawmen general search warrants. A third permits mass arrests, indefinite police detention and interrogation of suspects in the hope of extracting a confession. These may be the easy way to enforce the law, but the experience of centuries shows that convenience of the police is not synonymous with public interest or necessity. On the contrary, the framers of our Federal Constitution wrote into the Fourth and Fifth Amendments the view that the paramount necessity of our kind of national life is to confine police activity within well defined limits, even though the framers were practical men who well understood that such restraints on police would enable an occasional criminal to escape the law.

Wire Tapping Is More Dangerous Than Other Forms of NecesSary Police Surveillance

Too much of the opposition to wire tapping has contented itself with the observation that it is "dirty business." 8 That's not enough, for there is an unavoidable element of dirty business in all penal law enforcement. Capital punishment and long imprisonment are in themselves repulsive measures, cruel not only to the miscreant but to his innocent family. In the field of criminal investigation, the law tolerates much that would offend sensitive spirits. Police must eavesdrop, spy, employ stool pigeons, plant informants inside conspiracies. ${ }^{9}$ Those who would withhold authority to tap telephone wires have some obligation to show wherein this practice is worse or more dangerous than others admittedly necessary.

The chief difference between wire tapping and other forms of surveillance is the extent of its intrusion into the privacy of people who

8. See Olmstead v. United States, 277 U.S. 438, 470 (1928) (dissenting opinion of Justice Holmes).

9. But cf., Donnelly, Conments and Cazeats on the Wire Tapping Controversy, 63 YaLE L.J. 799, 805-07 (1954). 
are not even suspected of crime. For example, while tapping one telephone the police of New York recorded conversations involving, at the other end, The Julliard School of Music, Brooklyn Law School, Consolidated Radio Artists, Western Union, Mercantile Commercial Bank, several restaurants, a drug store, a real estate company, an importer, many lawyers, a stationery store, a dry cleaner, numerous bars, a garage, and the Prudential Insurance Company. ${ }^{10}$ In the Coplon case, the FBI recorded talks between the defendant and her mother, a quarrel between a husband and wife who had no connection with the case, and conferences between the defendant and her lawyer. ${ }^{11}$ Sometimes it is said that innocent people have nothing to fear from their conversations being overheard. But this ignores the nature of conversation as well as the fact that most people have some aspects of their lives that they do not wish to expose. Free conversation is often characterized by exaggeration, obscenity, agreeable falsehoods, and the expression of anti-social desires or views not intended to be taken seriously. The unedited quality of conversation is essential if it is to preserve its intimate, personal and informal character. How anxious people are to preserve this unedited aspect of telephone conversations can be seen from the public reaction against the recording of telephone conversations even by one of the parties to the call. This gave rise to the FCC regulation requiring warning signals on lines to which recording devices are attached. ${ }^{12}$ The uproar in the Army-McCarthy hearings over the transcribed telephone conversations is another illustration. The objection of course is even more serious when it becomes a matter of having one's telephone conversations recorded by police agents. Government officials and business and political leaders are beginning to hesitate to employ the telephone, so that we may be reaching a stage where the telephone's usefulness as an instrument of commerce and government is being impaired, without demonstrable gains in law enforcement.

All this suggests that one clear need in the field of wire tap legislation is unequivocal prohibition of such wire tapping as we do not choose to authorize. This is needed because the present law ${ }^{13}$ makes it

10. Westin, The Wire Tapping Problem: An Analysis and A Legislative Proposal, 52 CoL. L. Rev. 165, 188 n.112 (1952).

11. Donnelly, supra note 9, at 804-05.

12. Use of Recording Devices in Connection with Telephone Service, 12 F.C.C. 1005,1008 (1948).

13. "No person receiving or assisting in receiving, or transmitting, or assisting in transmitting, any interstate or foreign communications by wire or radio shall divulge or publish the existence, contents, substance, purport, effect, or meaning thereof, except through authorized channels of transmission or reception, to any person other than the addressee, his agent, or attorney, or to a person employed 
unlawful to "intercept and divulge" and the Department of Justice has interpreted this as punishing wire tapping only when the intercepted communication is disclosed by the intercepting agent to someone outside the government. Likewise it would appear that any unauthorized private tapper is immune unless it can be proved that he passed along the intercepted communication. ${ }^{14}$ Despite the unsatisfactory character of this interpretation, which would legitimate unrestricted wire tapping so long as the information was used only within the executive department and not divulged in court or elsewhere, administration proposals do not undertake to make unauthorized wire tapping itself a crime.

Returning to the comparison of wire tapping with other surveillance practices, it appears that wire tapping is a more drastic interference than is constitutionally permissible under search warrant. A search warrant must specify the things for which the officer is to search and, in general, these must be either articles used to commit the crime or else the proceeds of crime. A search for an object of purely evidentiary significance would almost certainly be held unconstitutional, as in case the warrant purported to authorize the seizure of a personal diary containing an account of the alleged crime. But wire tapping is unavoidably a hunt for evidence, pure and simple, $i . e$., for incriminating admissions. And since no one can forecast when the incriminating admission will be made, the hunt may have to go on for months, as against the specific and limited temporal authority granted by the ordinary search warrant for tangible things. The administration proposal sets no time limit on the continuance of an authorized tap; even the more restricted bill sponsored by the late Senator McCarran authorizes six months of wire tapping, with provision for renewal. ${ }^{15}$

or authorized to forward such communication to its destination, or to proper accounting or distributing officers of the various communicating centers over which the communication may be passed, or to the master of a ship under whom he is serving, or in response to a subpoena issued by a court of competent jurisdiction, or on demand of other lawful authority; and no person not being authorized by the sender shall intercept any communication and divulge or publish the existence, contents, substance, purport, effect, or meaning of such intercepted communication to any person; and no person not being entitled thereto shall receive or assist in receiving any interstate or foreign communication by wire or radio and use the same or any information therein contained for his own benefit or for the benefit of another not entitled thereto; and no person having received such intercepted communication or having become acquainted with the contents, substance, purport, effect, or meaning of the same or any part thereof, knowing that such information was so obtained shall divulge or publish the existence, contents, substance, purport, effect, or meaning of the same or any part thereof, or use the same or any information therein contined for his own benefit or for the benefit of another not entitled thereto: Provided, That this section shall not apply to the receiving, divulging, publishing, or utilizing the contents of any radio communication broadcast, or transmitted by amateurs or others for the use of the general public, or relating to ships in distress." (Italics added.) 48 STAT. 1103 (1934), 47 U.S.C. $\$ 605$ (1952).

14. Senate Hearings, supra note 1 , at 14.

15. See star note at p. 157 supra. 
Wire tapping is more intrusive than authorized search for tangibles for the additional reason that the subject is less likely to become aware of the intrusion. A citizen can take action against a Government agent who breaks into his house unreasonably or seizes property improperly. Not so the victim of wire tapping. Only in the unusual case where the tap yields evidence that is made public in court proceedings can a person whose privacy has been invaded learn of the fact. The restraining effect of complaints by injured parties is thus largely removed in wire tapping. In this connection it should be noted that the wire tapping proposals contemplate tapping of anyone's wire, not merely that of a suspect. It is interesting to speculate what chance wire tapping legislation would have if it required the Government to notify each person, not involved in the alleged offense, whose communications were intercepted. I should suppose that public protest by ordinary law abiding citizens who learned that their communications had been intercepted and recorded would be prompt and overwhelming. If that is the correct assumption, permissive wire tap legislation can be passed and kept on the books only so long as the people affected are kept ignorant of its operation.

A final special difficulty of surveillance by wire tapping arises from the assertion of the Department of Justice that wire tapping cannot practicably be subjected to judicial control, ${ }^{10}$ in the way that search warrants must be justified before commissioners and magistrates. The arguments which the Department of Justice advances for making it the sole judge of the propriety of its own wire tapping are not especially convincing. There is talk of the necessity for speedy action, as if the decision to tap a wire would have to be made on the run, although the tap is to operate for six months or a year. There are forebodings of "leaks" through the judiciary, not supported by actual experience under the New York law which requires judicial warrants. In any event, the Department of Justice position on warrants only underlines the possibilities of abuse in the bill which it seeks, especially taking into account the certainty that not the Attorney General but some subordinate will in practice make the critical decision.

Comparing wire tapping with stool pigeon and eavesdropping techniques, the former appears as the more significant threat to the ordinary individual's sense of security in his personal relationships. The possibility of betrayal by an associate is a known risk of every relationship, and most people are content with the opportunity to gauge that risk according to their appraisal of the other person's character. A person who does not wish to be overheard can take precautions which

16. Senate Hearings, supra note 1 , at 16-22, 28. 
will ordinarily be effective. The remote and invisible eavesdropper-bywire is not someone whom the speaker has elected to trust, but an unknown and practically indetectable intruder, the very possibility of whose existence may interdict the use of the telephone by honest folk as well as criminals. I do not pause here to examine how far the present argument might be applicable to non-wire-tapping devices, e. $g$., the detectaphone which amplifies sound waves transmitted through solid walls, and so enables the police to eavesdrop from the outside, although the suspect may think he is in the privacy of his own apartment.

\section{What Crimes Should Be Subject to Wire Tapping INVESTIGATION}

Assuming that a case can be made out for wire tapping in some situations, it becomes important to confine the procedure to situations of clearest necessity and least danger. One way of doing that is to specify the serious crimes where wire tapping may be used. Needless to say, there is wide disagreement as to what offenses are sufficiently grave. One test which might have been thought appropriate would be the severity of the maximum punishment that can be imposed for the crime. A list based on this principle would have included not only such national security offenses as treason and espionage, but also capital offenses like murder and kidnapping. The administration proposals stick to the national security test, which is more restricted in failing to provide for the most serious offenses against individuals, but much broader in another respect, for there are blanketed in many offenses arising under latter-day internal security measures such as the Subversive Activities Control Act.

The most questionable inclusion in the administration wire tapping proposals is sedition. Sedition as a crime is itself fraught with danger to freedom of speech. This difficulty inherent in the crime of sedition is aggravated when police officers are empowered to pursue subversive talk even on the privacy of the wires. When it comes to sedition many of the previously discussed objections to wire tapping operate in their most acute form. Evanescent anti-Government remarks taken out of context can easily be made to sound more frightful than their true import. The conspiracy dragnet is at its widest. Whole political parties and the amorphous group called fellow-travelers become legitimate objects of surveillance. If the political and prosecuting arm of government is to be its own judge of the necessity for wire tapping, as under the administration proposals, and in an atmosphere such as has prevailed in recent years, one can hardly see effective limits on the spying 
upon government officials and opposition elements. Some of the reports emanating from Washington in relation to the use of wire tapping and lie detectors in the State and Defense Departments would indicate that the first and most obvious result of this kind of pursuit of national security is to undermine the morale of our own government officials.

\section{Some Necessary Safeguards in ANy Wire Tap Legislation}

Testimony before the congressional committees showed that wiretap recordings can be easily and undetectably edited and altered. ${ }^{17}$ It is therefore essential that any legislation include provision, not found in the administration proposals, to assure the integrity of the recording. Official tapping should, in the first place, have to be recorded. The use of agents' recollection of the content of intercepted messages appears to be unjustified. ${ }^{18}$ Original recordings should be sealed until returned to the custody of the authorizing agency. Where intercepted communications are to be introduced in a criminal trial, defense counsel should have access in reasonable terms to the original recordings. Finally, in undertaking to experiment with a feared surveillance device, it would seem prudent to call for a periodic review of the conditions of its use, by some disinterested group whose report will carry weight with Congress and the public.

\section{Tapping with One Party's Permission}

The administration proposals fail to take one step which might legitimately be taken to clarify or affirm the right to make a recording of a telephone conversation upon permission of one of the parties to the call. This would be especially useful in cases of kidnapping, extortion, bribery, and the like, where the intended victim calls in the law. Under these circumstances the crime itself is likely to be committed by telephone during the specific conversation which the officer is invited to overhear. The situation does not differ ethically or practically from the case where an intended victim secretes a policeman in his own home to overhear an attempted extortion. Ordinary use of the phone is not imperiled by a practice limited as suggested. The risk to which the non-consenting party is subjected is not really a wire tapping risk but the risk of betrayal by the other party who acquiesced in the tap,

17. Robert Coar, Director of the Joint House-Senate Radio Facility, testified that a recording of a speech by Winston Churchill was altered to significantly change the meaning without detection by reporters who heard the speech as it was delivered. Senate Hearings, supra note 1 , at 112.

18. On Lee v. United States, 343 U.S. 747 (1952), rehearing denied, 343 U.S. 848 (1952). 
a risk inherent in any form of communication with him. The present doubt as to the lawfulness of having even one's secretary record a telephone conversation from another extension of the same phone derives from the decision of the Second Circuit, ${ }^{19}$ that dual listening at the end of the line constitutes "interception." One can share Judge Learned Hand's revulsion to this as a practice in ordinary circumstances; but the niceties of ordinary relations cannot, as pointed out previously, be the test of enforcement practice.

\section{CONCLUSION}

If in the foregoing observations I have taken too niggardly a view of the powers to be entrusted to the government, I can only say that in such matters it is well to err on the side of caution. Two centuries ago a Philadelphia lawyer named John Dickinson wrote: "A perpetual jealousy respecting liberty is absolutely requisite in all free states. Liberty is never exposed to so much danger, as when the people believe there is the least." 20

19. United States v. Polakoff, 112 F.2d 888 (2d Cir.), cert. denied, 311 U.S. 653 (1940).

20. Bowen, John Adams and the American Revolution 309 (1950), quoting from Dickinson, Letters from a Farmer in 2 Life ANd Writings 386, 393 (1895). 